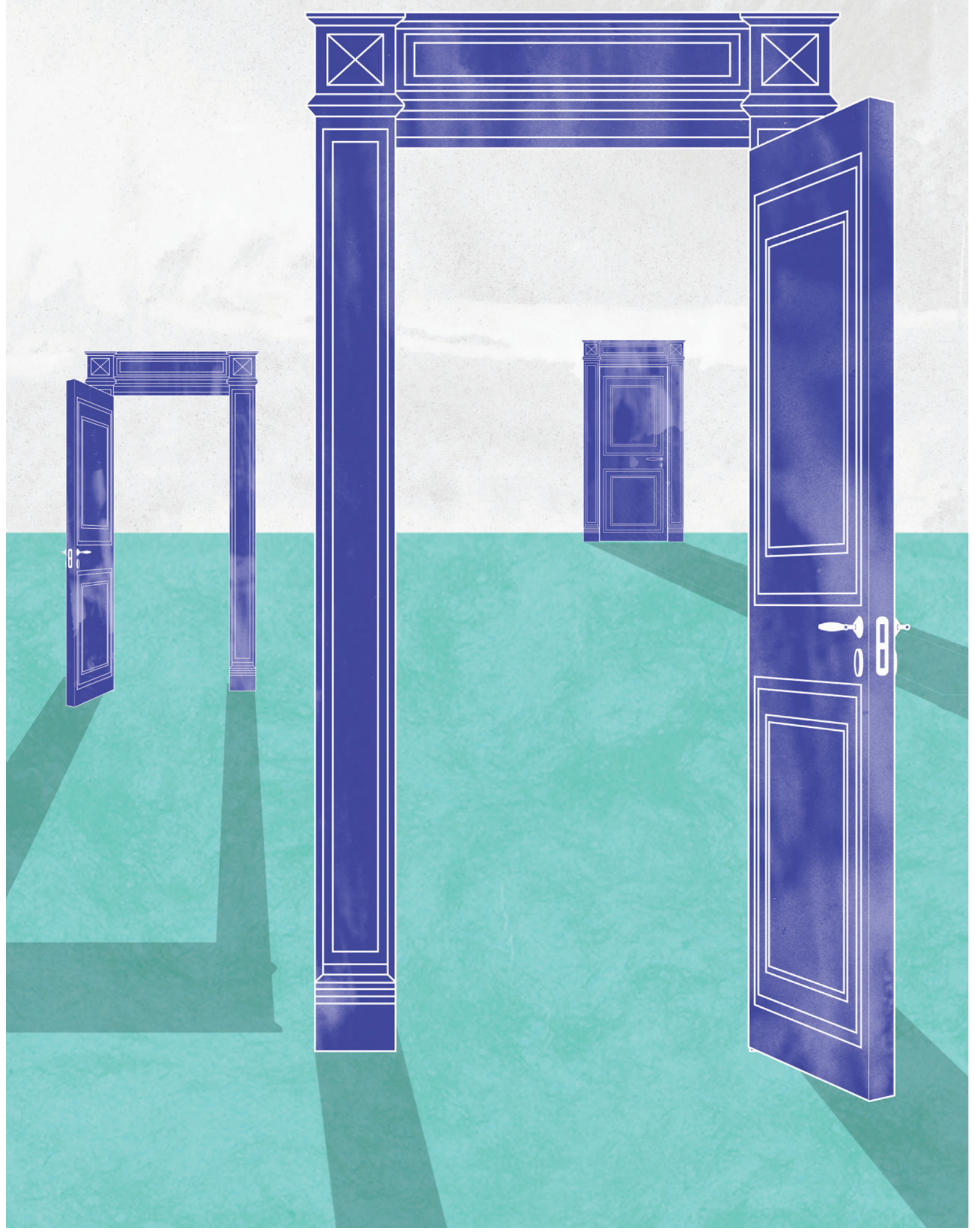




\title{
‘Et pour les Belges la même chose’?
}

\author{
Het Vlaamse aandeel in de BMGN
}

\author{
MARC BOONE EN TOM VERSCHAFFEL
}

Bijdragen en Mededelingen betreffende de Geschiedenis der Nederlanden was en is een Nederlands-Belgisch project. Belgische, in de realiteit enkel Vlaamse, historici hebben een rol gespeeld in de redactie en als auteurs van bijdragen. Het aandeel van het Zuiden is altijd kleiner geweest dan dat van het Noorden. Het tijdschrift poogde via een meestal paritaire samenstelling van de redactie en initiatieven, zoals comparatief opgezette themanummers en fora, de balans te herstellen. Aangezien het tijdschrift, zeker wat het Zuiden betreft, nauw verbonden was met de universitaire vakgroepen geschiedenis, in het bijzonder die van Gent en Leuven, weerspiegelen de evoluties van dit Belgische aandeel algemene verschuivingen in het academisch bedrijf. Uitbreiding van de onderzoeksfinanciering zorgde voor een aangroei, een verjonging en een vervrouwelijking van het auteursbestand en van de redactie. Ook andere ontwikkelingen in het historisch bedrijf van de voorbije halve eeuw, zoals het verschijnen van nieuwe tijdschriften en de internationalisering van het onderzoek, hadden een impact op de plaats van het tijdschrift en bijgevolg ook op Vlaamse bijdragen en hun auteurs.

Bijdragen en Mededelingen betreffende de Geschiedenis der Nederlanden was and is a Dutch-Belgian project. Belgian, though in fact only Flemish, historians have edited and authored contributions. The share from the South has always been smaller than that from the North. Via a generally balanced composition of the editorial board and initiatives, such as comparatively structured special issues and forums, the journal aimed to restore the balance. Since the journal, especially in the South, was closely affiliated with university history departments, those of the universities of Ghent and Leuven in particular, the evolutions of this Belgian share therefore reflect general shifts in academia. Expansion of research financing brought about accretion, rejuvenation and feminisation of the stock of authors and editors alike. Other developments in historical 
scholarship from the past half century, such as the appearance of new journals and internationalisation of research, had an impact on the positioning of the journal and consequently on Flemish contributions and their authors as well.

Een historisch tijdschrift onder de titel Bijdragen en Mededelingen betreffende de Geschiedenis der Nederlanden moet uiteraard de meervoudsvorm 'Nederlanden' eren, en dus stond van bij de aanvang van de BMGN de inbreng van Belgische auteurs en redactieleden op de agenda. De titel vestigt de aandacht op een specifieke problematiek van de geschiedenis der Nederlanden, ooit in een bijdrage in dit tijdschrift door de Engelse kenner van de Reformatie, Alastair Duke, omschreven als 'the elusive Netherlands', een variant op het 'tuchteloos probleem' van Ernst Kossmann. ${ }^{1}$ Wat deze specifieke problematiek betreft, alluderen we op de eb en vloed van een streven naar eenheid en het benadrukken van particuliere eigenheid, maar vooral het onmiskenbaar delen van een gemeenschappelijke geschiedenis. Nochtans was bij de fusie van de twee tijdschriften die uiteindelijk in 1969 in de Bijdragen en Mededelingen zijn uitgemond niet alles zomaar evident. ${ }^{2}$ In hun geschiedenis van het (Nederlands) Historisch Genootschap wijzen Leen Dorsman en Ed Jonker erop dat in de schoot van dit Genootschap bij de overname van de Bijdragen voor de Geschiedenis der Nederlanden twee problemen werden gesignaleerd: de bronnen en de Belgen! ${ }^{3}$

De achtergrond voor het tweede 'probleem' situeerde zich in de vrees voor het doorleven van enig Groot-Nederlands gedachtengoed, dat zich in de aanloop naar en tijdens de Tweede Wereldoorlog gemanifesteerd en gecompromitteerd had in de Nederlandsche Historiebladen, de in 1938 door Pieter Geyl opgerichte voorloper van de Bijdragen voor de Geschiedenis der Nederlanden. ${ }^{4}$ Bij de oprichting van het nieuwe tijdschrift in 1969 werd de Groot-Nederlandse gedachte afgezworen en verdween de Zuid-Afrikaanse kroniek, dat andere symptoom van het denken in termen van een Nederlandse

1 Alastair Duke, 'The Elusive Netherlands. The question of national identity in the Early Modern Low Countries on the Eve of the Revolt', Bijdragen en Mededelingen betreffende de Geschiedenis der Nederlanden 119:1 (2004) 10-38. DOI: https://doi. org/10.18352/bmgn-Ichr.5967; Ernst H. Kossmann, Een tuchteloos probleem. De natie in de Nederlanden (Leuven 1994). gelegenheid van de laatste aflevering van deel honderd van de BMGN', Bijdragen en Mededelingen betreffende de Geschiedenis der Nederlanden 100:4 (1985) 576-587. DOI: https://doi.org/10.18352/ bmgn-Ichr.2655.
3 Leen Dorsman en Ed Jonker, Anderhalve eeuw geschiedenis. (Nederlands) Historisch genootschap, 1845-1995 ('s-Gravenhage 1995) 100.

4 Dorsman en Jonker, Anderhalve eeuw geschiedenis, 95, en Pieter Van Hees, 'Van Nederlandsche Historiebladen tot Bijdragen voor de Geschiedenis der Nederlanden', Tijdschrift voor Geschiedenis 99:3-4 (1986) 476-506. Zie ook Lode Wils, 'De Grootnederlandse geschiedschrijving', Revue belge de Philologie et d'Histoire/Belgisch Tijdschrift voor Filologie en Geschiedenis 61:2 (1983) 322-366. DOI: https://doi.org/10.3406/ rbph.1983.3419. 
'stam'. ${ }^{5}$ Natuurlijk werden Belgen in de redactie opgenomen en richtte de inhoud van het tijdschrift zich op de geschiedenis van 'alle’ Nederlanden, versta niet enkel de Nederlandstalige gewesten, die bij uitstek het actieterrein van de Groot-Nederlandse 'stam' uitmaakten.

Wat het probleem van de bronnen betreft: Kossmann, de eerste hoofdredacteur, had al in 1968 het bestuur van het Historisch Genootschap deelachtig gemaakt van zijn vrees dat de Bijdragen en Mededelingen door Belgische bronnenpublicaties zou kunnen worden overspoeld. Een onterechte vrees, zo bleek ook achteraf, die ook voorbijging aan het bestaan van de Belgische Koninklijke Commissie voor Geschiedenis, die al sinds 1837 ruimte voorzag voor 'kleine bronnenedities' in haar Handelingen/Bulletin. ${ }^{6}$ Hoe dan ook, de allereerste redactievergadering van de BMGN op 4 juli 1969 vond plaats in België, in het Leuvense Instituut voor Nieuwe Geschiedenis, en de rol van Kossmann bleek in vele opzichten doorslaggevend. ${ }^{7}$ Toch bleef de beginperiode, zoals ook gereconstrueerd door oud-redactievoorzitter Klaas van Berkel, er een van aarzeling en zelfs enig wantrouwen. De schaduw van het Groot-Nederlandse gedachtegoed bleef over de onderneming hangen en de interne relaties tussen de vertegenwoordigers van de 'oorspronkelijke' tijdschriften waren niet altijd even harmonisch. Tijdschrift en vereniging kenden evenwel een geslaagde doorstart met het in december 1972 in Groningen georganiseerde internationale Huizingacongres, ter herdenking van de honderdste verjaardag van Johan Huizinga, waarvan de teksten in het tweede nummer van 1973 en ook als aparte publicatie verschenen. ${ }^{8}$

\section{De redactie}

Een vanzelfsprekende benadering van de inbreng van Belgische historici in de BMGN ligt vervat in hun plaats en rol in de redactie. Een eerste vaststelling is

$$
\text { de Vlamingen?', Jaarboek van de Maatschappij }
$$

6 Zie de website van de Koninklijke

Commissie voor Geschiedenis: http:// commissionroyalehistoire.be/nl/accueil_nl.html.
De handelingen zijn integraal beschikbaar via https://www.persee.fr/collection/bcrh.

7 Klaas van Berkel, 'E. H. Kossmann als redacteur van de Bijdragen en mededelingen', Bijdragen en Mededelingen betreffende de Geschiedenis der Nederlanden 119:1 (2004) 1-9. DOI: http://doi. org/10.18352/bmgn-Ichr.5966.

8 Het was meteen ook de start van een tot de dag van vandaag aanhoudende Huizingarevival: Bijdragen en Mededelingen betreffende de Geschiedenis der Nederlanden 88:2 (1973) 143-377 en Willem Koops, Ernst Kossmann, en Gees van der Plaat (reds.), Johan Huizinga 1872-1972. Papers delivered to the Johan Huizinga Conference 11-15 December 1972 (Den Haag 1973). 
alvast dat alle Belgische redacteuren Vlamingen waren, om precies te zijn: cultureel en bestuursmatig deel uitmakend van het Nederlandstalig deel van België dat als de huidige regio Vlaanderen bekend staat. Hoewel 'de Nederlanden' ook de Franstalige provincies van België omvatten, en historisch gesproken ook Luxemburg en een deel van Noord-Frankrijk, hebben Franstalige Belgen nooit deel uitgemaakt van de redactie. De vertegenwoordiging van de 'Zuidelijke' historici daarin weerspiegelt dan ook het Vlaamse academische landschap: de universiteiten van Gent en Leuven zijn in 1969, wanneer de BMGN van start gaat, 'volledige' universiteiten. In 1817 werd de Gentse als rijksuniversiteit door Willem I opgericht. De Leuvense werd in 1834 als katholieke universiteit gesticht: eerst in Mechelen, de vestigingsplaats van het aartsbisdom en als zodanig de katholieke hoofdstad van het land, maar een jaar later werd ze al overgebracht naar Leuven, waar al eeuwenlang een universiteit had bestaan (1425-1797). Nadat die in de Franse periode was verdwenen, creëerde Willem I ook hier in 1817 een rijksuniversiteit, die na de Belgische onafhankelijkheid werd opgedoekt. In 1969 werd de katholieke universiteit gesplitst in een Nederlandstalige universiteit, die in Leuven bleef, en een Franstalige, die werd gevestigd in Louvain-la-Neuve, een nieuwe stad net over de taalgrens. ${ }^{9}$ Ook Brussel kende met de Vrije Universiteit Brussel een Nederlandstalige universiteit: deze werd als vrijzinnige en aanvankelijk antiklerikale onderwijsinstelling opgericht in 1969, als afsplitsing met aparte rechtspersoonlijkheid van de Université Libre de Bruxelles, die actief was sinds 1834. Aan deze instellingen werd dus in 1970 een volledige Nederlandstalige opleiding geschiedenis in de twee cycli aangeboden, toen nog kandidaturen en licenties genoemd, nu bachelor en master. De Antwerpse universiteit zou in 2003 definitief uit de startblokken komen als een fusie van het Rijksuniversitair Centrum Antwerpen, de Universitaire Instelling Antwerpen en de Universitaire Faculteiten Sint-Ignatius Antwerpen (UFSIA), waarvan de UFSIA de enige was die kandidaturen in de geschiedenis aanbood. Pas vanaf dat moment werd in Antwerpen een volledige opleiding geschiedenis in de twee cycli georganiseerd.

Van bij de aanvang van de BMGN is het aandeel van aan de KU Leuven gelieerde historici in de redactie erg uitgesproken. In 1970 behoorden Jan Arthur Van Houtte, Maurits De Vroede en Raymond Van Uytven tot de eerste generatie redacteuren. Van Uytven was op dat ogenblik weliswaar Vos en Ruben Mantels, De stad op de berg. Een en zal over enkele jaren haar zeshonderdste verjaardag vieren. In 1909 vierde de universiteit geschiedenis van de Leuvense universiteit sinds 1968 (Leuven 2005). Ook Gent kende een bewogen nog haar vijfenzeventigste verjaardag, in 1927, met enkele jaren vertraging door de nasleep start: het Voorlopig Bewind dat na de revolutie van 1830 aan de macht kwam schrapte er onder van de Eerste Wereldoorlog, vierde zij haar vijfhonderdste verjaardag. Zie onder meer Emiel meer de faculteiten Letteren en Wetenschappen die pas in 1835 opnieuw werden ingericht, zie: Gita Lamberts en Jan Roegiers, Leuven University, 1425Deneckere, Uit de ivoren toren. 200 jaar Universiteit 1985 (Leuven 1990), en Jo Tollebeek en Liesbet Gent (Gent 2017) 20-23. 
als hoogleraar verbonden aan de Antwerpse faculteit UFSIA, maar was wel een product van de Leuvense school. ${ }^{10}$ Pas in 1975 trad de eerste Gentse historicus, de vroegmodernist Michel Baelde, tot de redactie toe. Van de in het totaal 26 Belgen die tot de redactie hebben behoord, hadden niet minder dan 12,5 (of $48 \%)^{11}$ een KU Leuven-signatuur, tegenover 8 (of $30 \%)^{12}$ die aan de UGent gelieerd waren. Eén Belgische redacteur, Wim Blockmans, heeft na een opleiding aan de UGent zijn verdere actieve loopbaan in Nederland uitgebouwd: eerst aan de Erasmus Universiteit Rotterdam, daarna aan de Leidse universiteit en het NIAs. Drie redacteuren zijn weliswaar aan de UGent opgeleid (11,5\%), maar waren op moment waarop ze tot de redactie toetraden aan het Algemeen Rijksarchief verbonden. ${ }^{13}$ Dat is uiteraard een nationale en tweetalige instelling, maar ook zijn vertegenwoordigers in de redactie waren tot nu toe uitsluitend Nederlandstaligen. De universiteiten van Brussel en Antwerpen verschijnen niet alleen laat, maar zijn ook 'ondervertegenwoordigd', met elk slechts één redacteur (of $4 \%){ }^{14}$

Als we per decennium kijken naar het zwaartepunt inzake onderzoek en periode wordt duidelijk dat voor 1990 redacteuren met een ancien régimeprofiel domineren (8) ten aanzien van collega's die de nieuwste of hedendaagse periode bestuderen (3). Vanaf de jaren 1990 is deze verhouding gekanteld, met 6 ancien régime-historici tegenover 9 specialisten van de hedendaagse periode. Nog meer uitgesproken is de genderratio. Het is de Gentse mediëvist Thérèse de Hemptinne geweest die in 2004 als eerste Belgische vrouwelijke redacteur dit bescheiden deel van het glazen plafond heeft doorbroken. Sindsdien is de genderratio bij de Belgen perfect in evenwicht. Meer zelfs: de eerste Belgische hoofdredacteur van het tijdschrift was een vrouw: Kaat Wils, die in 2013 toetrad. ${ }^{15}$

\section{Vriendenclub en netwerk}

Er zijn weinig aanwijzingen over de manier waarop de Belgische redacteuren geselecteerd werden, een systeem van coöptatie door de zetelende

origine en als mediëvist actief in Antwerpen, en vanaf 1990 ook buitengewoon hoogleraar in Leuven, zie Walter Prevenier, 'Raymond van Uytven: een getuigenis', Bijdragen tot de Geschiedenis 81 (1998) 9-23.

toetreding tot de redactie om Jan Arthur Van

Houtte, Maurits De Vroede, Raymond Van

Uytven (die we voor 50\% als Leuvens meetellen),

Herman Van der Wee, Emiel Lamberts, Erik Aerts, 
redactie spoort in elk geval met de persoonlijke ervaring van een van de ondergetekenden. Daarbij werd vooral rekening gehouden met zowel de spreiding over de universiteiten als met de zwaartepunten inzake onderzoekstraditie, wat onder meer blijkt uit het aantal Gentse mediëvisten dat in de redactie heeft gezeteld. ${ }^{16}$ Wel valt op dat zowat alle Belgische redacteuren, zeker in de eerste decennia, trouwe deelnemers waren aan de jaarlijkse Belgisch/ Vlaams-Nederlandse historische congressen. In een verslag van het congres dat in 1951 in Amsterdam was gehouden, stelde de jezuïet Michiel Dierickx onomwonden dat de deelnemende historici, 'de leidende geschiedkundigen van Noord en Zuid', ook samen het tijdschrift Bijdragen voor de Geschiedenis der Nederlanden uitgaven en de Algemene Geschiedenis der Nederlanden voorbereidden. ${ }^{17}$

De jaarlijkse ontmoetingen in de context van de Belgisch-Nederlandse historische congressen vonden voor het eerst plaats in 1939; vanwege de oorlog werd de draad pas in 1947 terug opgenomen. Oorspronkelijk heette het congres 'Belgisch-Nederlands', maar in de context van de herhaalde Belgische grondwetswijzigingen, de steun van de Nederlands-Vlaamse Taalunie, en een duidelijk gebrek aan interesse bij Franstalige Belgen, werd dit vanaf het 42 ste congres in 1995 te Tilburg in 'Nederlands-Vlaams' veranderd. Kenmerkend voor de bijeenkomsten was het beperkte aantal genodigden (twintig deelnemers uit elk land) en een selectie die rekening hield met de academische anciënniteit. ${ }^{18}$ Deze beslotenheid ging gepaard met een gemoedelijk en semi-informeel karakter van de bijeenkomsten, onder meer door de aanwezigheid van de 'echtgenotes' (later: 'partners'), en de uitstappen en maaltijden die steevast op het programma stonden. Zij boden alle kansen voor netwerking en het opzetten van collectieve ondernemingen.

In dit gremium werd de basis gelegd voor een ander gemeenschappelijk Nederlands-Vlaams historisch initiatief: de reeks Algemene Geschiedenis der Nederlanden (AGN). Dit project startte in 1949, wanneer het eerste deel verscheen, en zou in 1958 zijn afronding kennen met de publicatie van deel twaalf. Ook de auteurs van de AGN keerden zich nadrukkelijk af van een GrootNederlandse inspiratie; niet alleen omdat deze stroming tijdens de Tweede Wereldoorlog in extreemrechts vaarwater was terechtgekomen, maar ook omdat het op weerstand van belgicistisch ingestelde Vlaamse historici stuitte, die het beschouwden als een verloochening van de erfenis van Henri Pirenne. ${ }^{19}$ Andermaal treft men onder de medewerkers van de AGN veel BMGN-redacteuren

meegerekend, op de acht Gentse leden: Van

Caenegem, Blockmans, Boone, De Hemptinne,

Buylaert, en tot op zekere hoogte Van Bruaene.

17

historisch congres', Streven 4:9 (1951) 312-314

18

Beide principes werden met enige regelmaat voorwerp van discussie, zie over deze congressen:
Frits Hugenholtz, Harry van den Eerenbeemt en Louis Vos, Een beeld van een congres. BelgischNederlandse/Nederlands-Vlaamse Historische Congressen, 1939-2003 (Den Haag 2003) passim.

19 Els Witte, Voor vrede, democratie, wereldburgerschap en Europa. Belgische historici en de naoorlogse politiek-ideologische projecten (19441956) (Kapellen 2009) 251-252. 
aan, wat evenzeer geldt voor de zogenaamde ‘Nieuwe AGN', die tussen 1977 en 1983 in vijftien delen verscheen. Ook het initiatief voor het vaak in Nederland en België gebruikte handboek Geschiedenis van de Nederlanden, dat verscheen onder redactie van Hans Blom en Emiel Lamberts, kreeg op deze congressen gestalte. ${ }^{20}$

Hedendaagse lezers kunnen zich verwonderen over het belang van een op het eerste gezicht wat archaïsch ogend gremium als de NederlandsVlaamse congressen, maar hun rol valt ook samen met een tijdvak waarin de contacten tussen Noord en Zuid niet zo vlot en evident waren. De communicatie gebeurde bijna uitsluitend via een klassieke brief, weliswaar vanaf de jaren 1970 meer en meer vervangen door de fax wat de snelheid opdreef maar toch nog dicht bij een traditionele vorm van correspondentie bleef. En van andere institutionele mogelijkheden tot Vlaams-Nederlandse samenwerking, zoals de in 1994 door het Vlaamse Fwo en de Nederlandse Nwo opgestarte projecten van het Vlaams-Nederlands Comité voor Nederlandse Taal en Cultuur, was amper sprake. In de aanloop naar de start van de BMGN waren de Nederlands-Vlaamse congressen dus van groot belang en kan hun impact moeilijk overschat worden.

De inbreng van de Franstalige Belgische historici was, afgezien van enkele zeldzame deelnames bij de aanvang van de reeks congressen, zo goed als nihil, en dit gebeurde ook onder invloed van een andere reeks ontwikkelingen aan Belgische zijde. In 1988 waren immers, in de context van de derde Belgische staatshervorming, de bevoegdheden onderwijs en wetenschapsbeleid aan de taalgemeenschappen toegewezen, waarbij de Vlaamse en Franstalige onderwijs- en onderzoekswereld nog verder van elkaar verwijderd werden. ${ }^{21}$ De unitair Belgische organisatie voor wetenschapsbeleid, nu bekend als BELSPo, heeft in de voorbije decennia verschillende programma's ontwikkeld waarin enige ruimte was voor Vlaams-Nederlandse samenwerking, zoals het ook in het vakgebied geschiedenis benutte programma van de IUAP's (interuniversitaire attractiepolen). In het kader van verdere staatshervormingen en overheveling van bevoegdheden en middelen naar de gemeenschappen

Geschiedenis der Nederlanden', Ons Erfdeel 27:3 (1984) 321-328; Reginald De Schryver, 'De nieuwe Algemene Geschiedenis der Nederlanden. Een vergelijking met buitenlandse equivalenten', Bijdragen en Mededelingen betreffende de Geschiedenis der Nederlanden 101:3 (1986) 387-399. DOI: http://doi.org/10.18352/bmgn-lchr.2727; Hans Blom en Emiel Lamberts (reds.), Geschiedenis van de Nederlanden (Rijswijk 1993), gevolgd door diverse nieuwe edities en een Engelse vertaling (1999).
21 Het sinds de oprichting in 1928 unitaire Nationaal Fonds voor Wetenschappelijk Onderzoek werd vanaf 1988 door de Nederlands- en Franstalige gemeenschappen gefinancierd. In 1992 volgde de splitsing van de Raad van Bestuur, in 1996 werd een volwaardige Nederlandstalige vleugel in het leven geroepen en in 2006 volgde de volledige ontmanteling van de oude unitaire instelling, zie: 'Geschiedenis', Fwo, https://www.fwo.be/nl/het-fwo/profiel/ geschiedenis/ (geraadpleegd op 6 januari 2020). 
in 2017 kwam aan deze kans op gemeenschaps- en grensoverschrijdende samenwerking echter een einde. ${ }^{22}$

Hoewel de Nederlands-Vlaamse historische congressen een besloten en ietwat geheimzinnige aangelegenheid waren van gevestigde academici die elkaar goed kenden, zorgden zij in de loop der jaren toch voor een zekere uitbreiding en stimulering. De groep werd bewust klein gehouden en anciënniteit speelde een rol bij het lidmaatschap, maar toch werden ook jongere collega's uitgenodigd, om aansluiting te vinden bij nieuwe benaderingen en inzichten en om het gevaar van intellectuele inteelt tegen te gaan. Zo werden veelbelovende jonge historici uitgenodigd om een lezing te houden, waarbij zij enigszins door de 'bonzen' van het vakgebied werden gekeurd. Voor sommigen werkte dit als een 'ingangsexamen', dat kon leiden tot een volwaardige toelating tot de groep. De leden die door overlijden of al te hoge ouderdom wegvielen, werden op die manier vervangen door jongere generaties historici. Toch werd de rekrutering lastiger. Onder de jongere historici nam het enthousiasme voor de ietwat oubollige bijeenkomsten, met hun nationale en generalistische benadering van de geschiedenis, af. Hun academische carrière was meer gebaat met deelname aan meer gespecialiseerde, internationale conferenties. Ook het 'trage' sociale karakter van de congressen beantwoordde niet meer aan de gewoontes en wensen van de jongere generaties (en in toenemende mate vrouwelijke) academici. Op het einde kenden de Nederlands-Vlaamse congressen een wat slepend bestaan. De laatste zevenenvijftigste editie vond plaats in 2012 in Leuven, het jaar voordien was het congres in Utrecht afgelast.

De afnemende rol van de congressen en de generatiewissel waarvan zij het gevolg was, wordt ook weerspiegeld in de evolutie van het type BMGNredacteur. Aanvankelijk waren dit vooral gevestigde professoren, voor wie het lidmaatschap van de redactie een soort van bekroning was, of in elk geval een bevestiging van het feit dat zij in het historische bedrijf van 'de Nederlanden' de top hadden bereikt. Na pakweg 2000 was dat niet meer het geval. Zeker, het redacteurschap bleef voorbehouden aan Vlaamse historici die een plaats hadden veroverd aan de gevestigde instellingen en universitaire vakgroepen, maar ze waren jonger dan hun voorgangers en het BMGN-redacteurschap kwam vroeger in hun carrière op hun pad. Ook dit hangt samen met het veranderende en verruimde academische landschap, waarin dit redacteurschap niet meer zowat het hoogst denkbare was, maar een engagement naast vele andere. Ook veranderingen in de wetenschaps- en geschiedbeoefening zelf verklaren de verschuivingen en de verjonging van de redactie. Voor een wetenschappelijk tijdschrift werd het belangrijker korter op de bal te spelen, de laatste stand en de nieuwe trends van het onderzoek te volgen, en in te zetten op debat en discussie: zaken die jongere academici geacht worden beter te kunnen dan hoogleraren die de top al hebben bereikt - en dus achter de rug hebben.

belspo/organisation/about_history_nl.stm (geraadpleegd op 6 januari 2020). 


\section{De bijdragen en de auteurs}

Redacteurs zijn regisseurs, en de veranderende samenstelling van de redactie wordt dan ook weerspiegeld in de regie die zij heeft gevoerd, en de veranderingen die zich daarbij ook in de bijdragen hebben voorgedaan. Een wat ouderwets genre als het 'in memoriam' - toch bij uitstek een genre waarin 'oude' historici worden geëerd en een element van zelfbewieroking zichtbaar is - verdween al snel uit het blad. ${ }^{23}$ Ook zien we een toename van thematische ordening en clustering aan de hand van themanummers en dossiers, en van debat en discussie. Een eerste beweging daarvan is al vanaf het einde van de jaren zeventig waar te nemen, kent een hoogtepunt in de jaren negentig, en zet zich op volle kracht door vanaf 2005 (zie grafiek 4). Deze verschuiving ging gepaard met de evolutie, wellicht ook de verjonging en misschien ook de vervrouwelijking van de redactie vanaf de jaren negentig. Aan de hand van gekozen thema's en debatten bepaalde zij in toenemende mate de agenda en onderwerpskeuze, en in functie daarvan trad zij actiever op bij het aantrekken van auteurs. Hierdoor werd het tijdschrift minder afhankelijk van spontane bijdragen, en verschenen iets meer artikelen van auteurs die niet uit de historische wereld stricto sensu of uit de gebruikelijke poel van 'historici van de lage landen' kwamen en wellicht niet uit eigen beweging voor de BMGN hadden geschreven. Als het debat erom vroeg, verscheen al eens een (Belgische) politicoloog, econoom of jurist in de kolommen - al bleven zij zeldzaam. De toename in absolute aantallen van Belgische bijdragen vanaf 2005 was niet zozeer het gevolg van een aangroei of toegenomen productiviteit van gevestigde historici, maar van een toenemend aantal bijdragen van thesis- of scriptiestudenten en promovendi, waarin vaak de stimulerende invloed van promotoren die lid waren van de redactie te herkennen was (zie grafiek 7).

Sinds 1970 hebben in totaal 158 Belgische auteurs in de BMGN gepubliceerd, in veruit de meeste gevallen als enige auteur, soms als co-auteur. ${ }^{24}$ 41 van hen publiceerden meer dan eens in het tijdschrift, 117 deden dat eenmalig. Van de zeven historici die vier of meer bijdragen hebben geleverd, zijn er vijf die zelf tot de redactie behoorden of op een bepaald moment daartoe hebben behoord. ${ }^{25}$ De uitzonderingen op deze regel zijn twee historici die al lang meedraaien in het Belgische historische bedrijf en sowieso zeer productief waren en nog zijn: Els Witte (6) en Lode Wils (4). Van alle Belgische auteurs zijn er slechts zes Franstalig (4\%). ${ }^{26}$ In de meeste gevallen beperkt hun memoriam van Egied-Idesbald Strubbe (1971), Louis Jadin, Raymond De Roover en Charles Terlinden (1973), en Raymond Van Uytven van Jan Dhondt (1973). recensies zijn hier buiten beschouwing gelaten. 
inbreng zich tot een artikel op uitnodiging of is hun bijdrage het resultaat van betrokkenheid bij een Vlaams-Nederlands onderzoeksproject. Een echte brugfunctie naar de wetenschappelijke productie in de Franstalige wereld is dit niet. Verwijzingen naar studies uit Frankrijk, tot in de jaren 1970-1980 toch een inspirerend gidsland inzake historisch onderzoek, kwamen in de context van de BMGN toch voornamelijk voor in de Nederlandstalige Belgische, maar ook Nederlandse comparatieve artikelen. Het aandeel vrouwelijke auteurs was aanvankelijk zeer beperkt: in de jaren 1970 publiceerden slechts drie Belgische vrouwen in de BMGN (of 7\%). Vanaf de tweede helft van de jaren 1980 nam hun aandeel toe en in de jaren 1990 en de jaren 2010 schommelde het rond de 40\% (in het eerste decennium van de eeuw was het tijdelijk weer gezakt naar 15\%). In absolute aantallen nam het aantal Belgische artikelen vooral vanaf 2005 toe, tot zes à zeven per jaargang (vergelijk met grafiek 6 en 7 ).

Als we de behandelde onderwerpen in de bijdragen van Belgische auteurs bekijken, dan blijkt ook hier aanvankelijk een overwicht van het ancien régime. In de eerste periode situeerden 60 tot $70 \%$ van de bijdragen zich op dat domein. In de tweede helft van de jaren tachtig kantelt deze verhouding, en sindsdien beslaat het aandeel hedendaagse geschiedenis tussen de 60 en (in de periode 2001-2005) 80\% van de artikelen. Zeer verrassend is deze verschuiving niet. Rond 1970 nam de beoefening van de nieuwste geschiedenis aan de Vlaamse universiteiten nog een bescheiden en ondergeschikte positie in. Onder aanvoering van Jan Dhondt, de befaamde Gentse mediëvist die zich na de Tweede Wereldoorlog tot contemporanist omschoolde, werden de aanvankelijk schaarse krachten aan de verschillende universiteiten gebundeld om deze nieuwe subdiscipline uit te bouwen. In 1955 was met het oog daarop een Interuniversitair Centrum voor Hedendaagse Geschiedenis (IUCHG) opgericht, dat in zijn Cahiers, de informeel zo genoemde 'blauwe reeks', talrijke werkinstrumenten publiceerde, hoofdzakelijk bibliografieën en persrepertoria. Ditzelfde netwerk lag ook aan de basis van het Belgisch Tijdschrift voor Nieuwste Geschiedenis, dat voor het eerst in 1969 werd uitgegeven. In de jaren 1980 was de institutionele achterstand weggewerkt en nam ook het aantal studenten en doctorandi dat voor de hedendaagse geschiedenis koos sterk toe (vergelijk met grafiek 2). ${ }^{27}$

Het kan niet verbazen dat de Belgische historici vooral ook Belgische inhoud inbrachten. Toch is dat niet uitsluitend het geval. In de eerste plaats is duidelijk dat het geheel-Nederlandse karakter van de BMGN auteurs aantrekt die zich in hun persoon en carrière en/of met hun onderzoek enigermate aan de scheiding van de Nederlanden onttrekken: dit betreft Belgische auteurs die in Nederland werken ${ }^{28}$, onderzoek doen over de Nederlandse

Liber amicorum Herman Balthazar (Gent 2003).

28 Zoals Wim Blockmans, Louis Th. Maes, Hugo de Schepper en Nele Beyens. 
geschiedenis ${ }^{29}$, en/of uitdrukkelijk over de verhouding tussen Noord en Zuid en de omgang met hun gezamenlijke geschiedenis reflecteren. ${ }^{30}$ Ook zijn een aantal bijdragen in de BMGN samen geschreven door Vlaamse en Nederlandse auteurs, al dan niet met een comparatief doel, of als resultaat van een gezamenlijk onderzoeksproject. ${ }^{31}$ De redactie poogde af en toe uitdrukkelijk de grensoverschrijding te bevorderen, onder meer door met een aantal dossiers en fora de comparatieve aanpak uitdrukkelijk te agenderen, Noord- en Zuid-Nederlanders over elkaars geschiedenis te laten reflecteren, en noordelijke en zuidelijke studies met elkaar te vergelijken. ${ }^{32}$ Zelfs als dat niet altijd gemakkelijk bleek, werd uitdrukkelijk gepoogd om ook over specifieke Nederlandse en Belgische onderwerpen, zoals de Nederlandse canon (2006) en de Belgische parlementaire Lumumba-commissie (2007), een perspectief van de andere kant van de grens aan de discussie toe te voegen. Toch blijft het aandeel van deze grensoverschrijdende bijdragen beperkt. Zoals de meeste Noord-Nederlandse historici schreven over de Noord-Nederlandse geschiedenis (vergelijk met grafiek 3), zo namen de meeste Zuid-Nederlanders de Belgische geschiedenis voor hun rekening - een taakverdeling die overigens ook in een gezamenlijk project als de AGN werd gehanteerd.

Uiteraard komen zeer verscheiden onderwerpen en subdomeinen in het tijdschrift aan bod, maar het is niet zo dat alle onderdelen van de geschiedenis van de (Zuidelijke) Nederlanden daarbij evenveel aandacht kregen. De aard van het tijdschrift en de soms uitdrukkelijke zoektocht naar onderwerpen die een zo groot mogelijk deel van de historische wereld in Noord én Zuid verbindt, werkt een keuze voor generalistische bijdragen en studies op het vlak van de volksonderwijs in België en Nederland (1977), Jo Tollebeek over geschiedschrijving en geschiedtheorie in Nederland (1995), Kaat Wils over Comte in Nederland (1996), Pieter Lagrou over het Srebrenica-rapport (2003) en over Loe de Jong (2015), en Antoon Vrints over de voedselvoorziening in Nederland tijdens de Tweede Wereldoorlog (2011).

De Schryver over de AGN (1986), Maria De Waele over de onderlinge beeldvorming tussen België en Nederland in de negentiende en de eerste helft van de twintigste eeuw (2000), en Erik Buyst en Wim Lefebvre over de Nederlandse economie tijdens de Tweede Wereldoorlog vanuit Belgisch perspectief (2004). Bijvoorbeeld Angelo De Bruycker en Djoeke van Netten over de migratie van wetenschappers tussen de Republiek en de Spaanse Nederlanden
(2008), Nico Wouters en Jan Julia Zurné over Jodenvervolging en daderprocessen in Nederland en België (2016), Hilde Greefs en Marjolein 't Hart over de suikersector in Antwerpen en Rotterdam 1795-1815 (2018). Of voor de studie van de periode van het Verenigd Koninkrijk (1815-1830), zoals door Brecht Deseure en Diederik Smit (2018) en Dieter Bruneel en Leon Wessels (2019). Bijvoorbeeld de Bourgondische periode (1980), de Duitse bezetting (1990), 'Parlementen in de Nederlanden' (2005), historische canons (2006), over landschap, natuur en nationale identiteit (2006), de geschiedenis en rol van de provincies (2008), onderzoekscommissies naar vredesmissies (2010), histories of masculinity (2012), historisch migratieonderzoek (2012), digital history (2013), historische televisie (2015), de Beeldenstorm (2016), de herdenking van de Eerste Wereldoorlog (2016), scholarly personae (2016) en het Huis van de Europese Geschiedenis (2018). 
politieke geschiedenis en de cultuurgeschiedenis in de hand. In combinatie met een toenemende focus op debat en discussie, verklaren deze factoren het ruime aandeel van bijdragen met een beschouwende en (in de ruime zin van het woord) historiografische inslag. De sociale en de economische geschiedenis en ook de geschiedenis van kerk en religie zijn geenszins afwezig, maar krijgen toch minder aandacht (vergelijk met grafiek 1). Verklaringen hiervoor liggen wellicht in het feit dat het onderzoek in deze subdomeinen in grotere mate geïnternationaliseerd was en gemakkelijker zijn weg vond naar andere publicatiekanalen. Maar ook de aard en de evolutie van het landschap van historische tijdschriften in de Nederlanden zelf vormt een verklaring: zo hebben de kerk- en godsdienstgeschiedenis er een stevige specifieke traditie, met zowel de aloude en internationale maar in de Leuvense universiteit gegroeide Revue d'Histoire Ecclésiastique (1900-) als het op de geschiedenis van het katholicisme in de Nederlanden gerichte Trajecta (1959-).

\section{Veranderend landschap}

De samenstelling van de redactie en auteursgroep, en de aard van de bijdragen die zij leverden, hangen dus samen - hoe zou het ook anders kunnen - met het landschap waarin het tijdschrift zich bevond en waarmee het rekening diende te houden. Naast de BMGN bestond en bestaat een ander oud en eerbiedwaardig tijdschrift, het Tijdschrift voor Geschiedenis (TvG), dat in 1886 werd opgericht. Het TvG onderscheidt zich van de BMGN door zich niet te beperken tot de geschiedenis van de Nederlanden, maar, zoals het op zijn website aangeeft, 'de geschiedenis van alle tijden en van de hele wereld' bestrijkt en dus een meer generalistisch karakter heeft. Toch heeft het $T v G$, als orgaan van de Nederlandse en Belgische (Vlaamse) historische wereld, veel aandacht voor de Nederlanden. Ook dit tijdschrift heeft een gemengde Belgisch-Nederlandse redactie en vist hiervoor (deels) in dezelfde vijver als de BMGN. ${ }^{33}$

Het Laaglandse landschap waarin de BMGN en het $T v G$ door hun respectabele ouderdom en door hun generalistische aanpak een centrale plaats bekleedden, is de voorbije halve eeuw grondig veranderd. De toename van het aantal geschiedenisstudenten, van de onderzoeksgelden en bijgevolg ook van het aantal projecten en doctorandi, zorgden niet alleen

hebben toegelegd, zoals in de actuele redactie onder meer Georgi Verbeeck en Werner

Thomas, specialisten van de respectievelijk Duitse en Spaanse geschiedenis. In de redactie van het TvG geldt geen numeriek evenwicht tussen Noordelijke en Zuidelijke leden. Onder

\author{
de vijftien actuele leden zijn één Vlaams \\ historicus die in Nederland werkt (Georgi \\ Verbeeck van de Universiteit Maastricht) en \\ drie vertegenwoordigers van de Vlaamse \\ universiteiten: Tim Soens (Antwerpen), Werner \\ Thomas (Leuven) en Anne-Laure Van Bruaene \\ (Gent), voormalig redactielid van de BMGN.
}


voor een uitbreiding maar ook een grotere diversificatie van het historisch onderzoek. Er was nood aan meer publicatiekanalen die aan de groeiende verscheidenheid en specialisatie konden voldoen. Groepen onderzoekers organiseerden zich in chronologisch of thematisch gedefinieerde verenigingen en werkgroepen, die soms ook een eigen tijdschrift startten. Zo verschenen een aantal 'eeuwtijdschriften'. Vanaf 1968 werd het Documentatieblad van de Werkgroep Achttiende Eeuw uitgebracht, dat sinds 1985 De Achttiende Eeuw heet. Deze uitgave beperkte zich tot de genoemde eeuw, maar verruimde tegelijk ook de actieradius en bood een forum aan historici, maar ook aan historisch-letterkundigen, kunsthistorici, filosofen en al wie zich, vanuit welke discipline dan ook, op de achttiende eeuw toelegt. Hetzelfde geldt voor De Negentiende Eeuw, dat sinds 1977 verscheen, en het vanaf 1985 uitgebrachte De Zeventiende Eeuw. De Negentiende Eeuw had een minder gemengde werking en redactie dan De Zeventiende en De Achttiende Eeuw, waarvan de Leuvense hoogleraar Jan Roegiers een van de drijvende krachten was, maar elk van deze tijdschriften publiceerde ook werk van Vlaamse historici.

Het is nuttig even stil te staan bij een tijdschrift dat in zijn eerste verschijningsvorm het een kwart eeuw heeft uitgezongen en dat ook de ambitie had de geschiedenis van Noord en Zuid te omvatten en daartoe een Belgisch-Nederlandse redactie kende. In 1975, kort na de doorstart van de BMGN, kwam het eerste nummer van het Tijdschrift voor Sociale Geschiedenis (TVSG) uit. Dicht aanleunend bij het Internationaal Instituut voor Sociale Geschiedenis (IISG) in Amsterdam richtte TVSG zich in eerste instantie op de studie van de arbeidersbeweging, niet enkel in de Nederlanden, maar wereldwijd. Deze oriëntatie werd in de loop der jaren uitgebreid naar de studie van 'sociale strukturen en processen', zoals in het redactioneel van het eerste nummer van TVSG te lezen valt. ${ }^{34}$ Opvallend daarin is dat de verwachting voor een samenwerking met 'de Nederlandstalige Belgische beoefenaren der sociale geschiedenis' wordt geformuleerd. En effectief, met ingang van het in februari 1976 verschenen vierde nummer treden twee Belgische redacteuren, Catharina Lis en Christiaan Vandenbroeke, aan. Zij waren respectievelijk werkzaam aan de vUв en de UGent. In 1999 fusioneerde TVSG samen met het 'NEHA-Jaarboek voor economische, bedrijfs- en techniekgeschiedenis' (opgericht in 1914) en het 'NEHA-Bulletin' (opgericht in 1986) tot het Tijdschrift voor Sociale en Economische Geschiedenis met een BelgischNederlandse redactie. Naar aanleiding van deze fusie publiceerde TvSG een handig overzicht van redacteuren en redactiesecretarissen, en een index van artikelen en recensies. Toenmalig redactiesecretaris Anton Schuurman schreef 
er een inleiding bij waaruit een aantal merkwaardige paralellen met de BMGN kunnen worden afgeleid. ${ }^{35}$ Van de 31 redacteuren waren er elf Belgen en wanneer we de 'institutionele' verankering bekijken, valt eenzelfde effect van interne coöptatie op dat we bij de Belgische vertegenwoordiging in de BMGNredactie meenden te onderkennen. Van de elf Belgische redacteuren hadden zes een UGent-achtergrond en waren vijf redacteuren afkomstig van de Vrije Universiteit Brussel. Pas na de fusie in het huidige Tijdschrift voor Sociale en Economische Geschiedenis traden academici van andere Belgische instellingen tot de redactie toe. ${ }^{36}$

Schuurman presenteerde in zijn overzicht ook enkele tellingen over de inhoud: in totaal publiceerde TvSG 417 artikelen, waarvan er 246 (59\%) expliciet op Nederland betrekking hadden, 63 (15\%) op België, en de rest op andere landen. Wat de verdeling over de historische periodes betreft, hadden 19 artikelen betrekking op de middeleeuwen, 94 op het ancien régime, 144 op de negentiende en 76 op de twintigste eeuw. Inhoudelijk constateerde Schuurman een duidelijke overgang van een traditionele geschiedenis van sociale bewegingen naar een structurele sociale geschiedenis, met vervolgens sinds circa 1985 een duidelijke opkomst van sociaal-politieke en sociaal-culturele geschiedenis, zonder dat daarbij de 'oude' belangstelling voor bijvoorbeeld sociale bewegingen was verdwenen. De oude thema's werden wel vaak op een fundamenteel andere manier aan de orde gesteld.

In België hebben ook historische tijdschriften bestaan die hun actieradius tot de Zuidelijke Nederlanden beperkten, al dan niet in uitdrukkelijke samenwerking tussen Nederlandstaligen en Franstaligen. Sinds 1922 publiceert het Belgisch Tijdschrift voor Filologie en Geschiedenis/ Revue Belge de Philologie et d'Histoire, in het Frans en het Nederlands studies, 'betreffende de klassieke, Romaanse en Germaanse filologie enerzijds en de geschiedenis van de oudheid, de middeleeuwen, de nieuwe tijd en de hedendaagse periode anderzijds'. ${ }^{37}$ Uitgegeven door de 'Société pour le Progrès des Études Philologiques et Historiques’ blijft het sterk verbonden met de Franstalige ULB-historici, wat in de jaren na de Tweede Wereldoorlog kortstondig tot een intern conflict heeft geleid toen de vraag werd

Schuurman, Tijdschrift voor Sociale Geschiedenis,

Register op de jaargangen 1 (1975) - 25 (1999)

(Hilversum 2000) 1-2.

Chris Vandenbroeke, Jos De Belder, Marc

Boone, Hanno Brand en Gita Deneckere; bij de

VUB gaat het om Catharina Lis, Patricia Van den

Eeckhout, Roger De Peuter, Peter Scholliers

en Harald Deceulaer. Hierbij moet worden

opgemerkt dat De Peuter als Belg destijds aan de
Universiteit Utrecht werkzaam was, terwijl Brand als Nederlander toen aan de UGent verbonden was. Het valt verder op dat slechts twee Belgen redactiesecretaris zijn geweest: De Peuter en Brand, niet toevallig twee vertegenwoordigers van deze 'hybride variant'.

37 Doelstellingen van het tijdschrift, te vinden op zijn website: 'Het Tijdschrift', Revue Belge de Philologie et d'Histoire - Belgisch Tijdschrift voor Filologie en Geschiedenis, https://www.rbph-btfg. be/nl_index.html. 
gesteld of de door de Duitse bezetter opgelegde tweetalige titel van het tijdschrift behouden diende te blijven. ${ }^{38}$ Het houdt ook sinds 1953 de evenzeer tweetalige bibliografie van de geschiedenis van België bij, zij het nu in samenwerking met het Algemeen Rijksarchief en de Koninklijke Commissie voor Geschiedenis. ${ }^{39}$ Ook de Belgische Vereniging voor Nieuwste Geschiedenis / l'Association belge d'Histoire contemporaine is een 'geheelBelgisch' en dus tweetalig genootschap, dat in 1974 is gesticht. Een volwaardig tijdschrift geeft zij niet uit, maar wel een Mededelingenblad (vanaf 1978), met aankondigingen, discussies en recensies, en de voorstelling van onderzoeksgroepen, projecten, archieven en collecties. ${ }^{40}$ Later gaf het Studieen Documentatiecentrum Oorlog en Hedendaagse Maatschappij (sOMA), het voormalige Navorsings- en Studiecentrum van de Geschiedenis van de Tweede Wereldoorlog, de Bijdragen tot de Eigentijdse Geschiedenis / Cahiers d'Histoire du Temps Présent (1996-2011) uit.

\section{Verengelsing en digitalisering}

Aan de bescheiden proliferatie van Belgische en Belgisch-Nederlandse historische tijdschriften vanaf het einde van de jaren zestig is intussen een einde gekomen. De toegenomen (internationale) publicatiemogelijkheden, de trend naar het elektronisch en in open access aanbieden van tijdschriften, en de toegenomen academische concurrentie die jonge onderzoekers noodzaakte om in te zetten op internationale 'A1-artikelen' en Nederlandstalige en nationale tijdschriften links te laten liggen, maakten het die tijdschriften moeilijker om het hoofd boven water te houden. Door de publicatiedruk die door beleidskeuzes in de meeste universiteiten in het begin van de eenentwintigste eeuw fors werd opgevoerd, deed zich vaak ook een omschakeling voor naar het Engels als publicatietaal, wat zoals verhoopt een erkenning door de grote citation index systemen gemakkelijker maakte (vergelijk met grafiek 5). In het geval van de BMGN bleef dat relatief beperkt, met de Engelse subtitel The Low Countries Historical Review die met ingang van jaargang 121 in 2006 op de kaft verscheen, het aantreden van een internationale advisory board en naderhand

\footnotetext{
De Société werd in 1874 opgericht en groeide in het interbellum uit tot een overkoepelende vereniging van Belgische historici. Ze werd de uitgeefster van de Revue Belge de Philologie et d'Histoire/Belgisch Tijdschrift voor Filologie en Geschiedenis, zie Els Witte, Voor vrede, democratie, 65-66 en passim over het tijdschrift, Marnix Beyen, Oorlog \& verleden. Nationale geschiedenis in Belgie en Nederland, 19381947 (Amsterdam 2002) 209, 386, en Ludo Milis, 'François-Louis Ganshof (1895-1980)', Revue Belge
}

de Philologie et d'Histoire/Belgisch Tijdschrift voor Filologie en Geschiedenis 59:2 (1981) 527-528. Koninklijke Commissie voor Geschiedenis, http:// commissionroyalehistoire.be/nl/bibliografie/ geschiedenisBelgie.html (geraadpleegd op 30 november 2020). Dit forum bestaat nog steeds, maar verschijnt sinds kort nog enkel digitaal: https://www. contemporanea.be/nl. 
ook het plan om in open access te verschijnen. ${ }^{41}$ De achtergrond hiervan bleek, zoals verwoord in het redactioneel van 2010, de erkenning als A-tijdschrift door de European Science Foundation. ${ }^{42}$

De verschillende tijdschriften met een relatief beperkte chronologische of thematische scope, zijn zo goed als allemaal in de loop van de jaren 2010 verdwenen of gefusioneerd tot doorgaans Engelstalige tijdschriften. De Zeventiende Eeuw en De Achttiende Eeuw zijn in 2017 opgegaan in het Engelstalige en door een Belgisch-Nederlandse redactie gedragen open access tijdschrift Early Modern Low Countries. ${ }^{43}$ De Negentiende Eeuw is op datzelfde moment omgevormd tot De Moderne Tijd: De Lage Landen, 1780-1940, met uiteraard ook een gemengde, zij het overwegend Nederlandse, redactie. En terwijl de redacties zo goed als altijd Belgisch-Nederlands gebleven zijn, werden de te verwachten aanpassingen ingegeven door de ambitie om die (internationale) A1-status te verwerven: een internationale advisory board, eventueel open access, een doorgedreven anonieme peerreview. Het Jaarboek voor Middeleeuwse Geschiedenis werd in 1998 voor het eerst uitgegeven. Dit tijdschrift kende vijftien afleveringen, waarvan de laatste in 2012 werd gepubliceerd. Parallel bestond ook het tijdschrift Millennium: tijdschrift voor middeleeuwse studies, opgestart in 1987 en eveneens stopgezet in $2012 .{ }^{44}$ De traditie van beide tijdschriften werd vanaf 2014 overgenomen door het jaarboek The Medieval Low Countries. An Annual Review. 45

De BMGN heeft de dubbele beweging van proliferatie en beperking van het omliggende landschap zonder al te veel problemen doorstaan. Zijn bestaansreden heeft, ook in Vlaanderen, nooit echt ter discussie gestaan. De uitbreiding van het historisch onderzoek en van het aantal onderzoekers (niet zozeer van het aantal hoogleraren, maar in elk geval van het aantal doctorandi) maakte het mogelijk de concurrentie het hoofd te bieden. De toename van het aantal historische tijdschriften in Vlaanderen, die onvermijdelijk ook voor bestaffing en bijdragen in dezelfde vijver moesten vissen, heeft de aantrekkelijkheid van de BMGN voor Vlaamse historici verminderd. Deze ontwikkeling verklaart wellicht het vrij beperkt aantal zuidelijke bijdragen in de periode 1980-2005. Met name in het midden van de jaren 1990 zijn er jaargangen geweest waarin geen enkel artikel van een

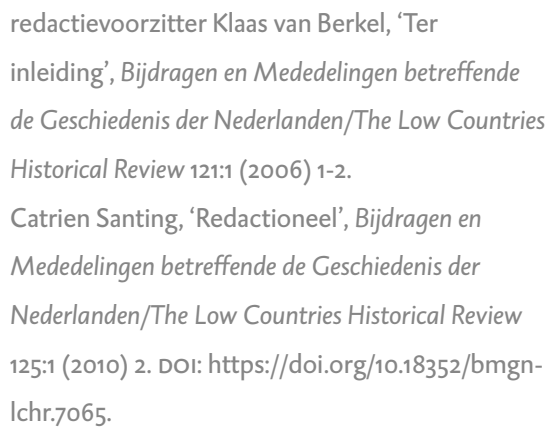

43 De Werkroep Achttiende Eeuw publiceert sinds 2017 wel nog steeds zelfstandig een jaarboek.

44 Uitgegeven door een aan de Katholieke Universiteit Nijmegen verbonden stichting, maar gepubliceerd bij uitgeverij Verloren in Hilversum.

45 Het Nederlandstalige jaarboek een initiatief van de Stichting bevordering middeleeuwse studies werd uitgegeven bij Verloren in Hilversum, haar Engelstalige opvolger bij Brepols in Turnhout. 
Belgisch auteur is verschenen. Deze periode ligt evenwel al lang achter ons. De krimp van het landschap, tenminste wat papieren tijdschriften betreft, heeft gezorgd voor een hernieuwde aantrekkelijkheid. Tegenover de internationale en digitale concurrentie, kan de BMGN nu weer gemakkelijker zijn specificiteit uitspelen en zich van aanloop uit België verzekeren.

Marc Boone is gewoon hoogleraar middeleeuwse geschiedenis aan de UGent, gastproffesor in Dijon, Parijs (Sorbonne en EHESS) en Milaan, en Francqui-

leerstoelhouder aan de ULB. Zijn onderzoek betreft de vergelijkende stadsgeschiedenis, de sociaal-politieke en economische geschiedenis van de (late) middeleeuwen, en de Bourgondische geschiedenis. Hij was onder meer redacteur van het TvSG en de BMGN en lid van de Koninklijke Vlaamse Academie van België voor Wetenschappen en Kunsten (KVAB). Recent was hij met Anne-Laure Van Bruaene, Bruno Blondé en Claire Billen redacteur van een synthese over stadsgeschiedenis: Gouden eeuwen. Stad en samenleving in de Lage Landen, 1100-1600 (2016) waarvan een Engelse (2018) en Franse versie (2021) is verschenen. E-mail: marc.boone@ugent.be.

Tom Verschaffel is hoogleraar Cultuurgeschiedenis aan de KU Leuven en KULAK. Zijn onderzoek betreft de geschiedenis van de geschiedschrijving, de brede historische cultuur en de visualisering van het verleden, het cultureel nationalisme, de geschiedenis van de culturele infrastructuur en culturele transfers, en de Belgische cultuurgeschiedenis van de achttiende en de negentiende eeuw. Hij schreef onder meer De vreugden van Houssaye: apologie van de historische interesse (met Jo Tollebeek, 1992), De hoed en de hond: geschiedschrijving in de Zuidelijke Nederlanden, $1715-1794$ (1998), Broedertwist: België en Nederland en de erfenis van 1830 (met Peter Rietbergen, 2005), Lotsverbonden ontrouw: de wankelmoedige verhouding tussen Noord en Zuid, 1585-1815 (2015) en De weg naar het binnenland. Geschiedenis van de Nederlandse literatuur 1700-1800: de Zuidelijke Nederlanden (2017). Recent publiceerde hij samen met Marjan Sterckx Sculpting abroad. Nationality and mobility in the nineteenth century (2020).

E-mail: tom.verschaffel@kuleuven.be. 